\title{
The effects of heat treatment on the nutritive value of coconut meal, and the prediction of nutritive value by chemical methods
}

\author{
BY M. H. BUTTERWORTH* \\ University of the West Indies, Faculty of Agriculture, St Augustine, Trinidad \\ AND HELEN C. FOX \\ Human Nutrition Research, Ministry of Development, Jamaica
}

(Received 13 November 1962-Revised 9 May 1963)

Coconut meal, the residual product after extraction of oil from the dried flesh of the coconut, is available in many parts of the world. In large areas of the tropics it is the only locally produced ingredient of feeding-stuffs that contains moderate amounts of protein (18-25\% of the dry matter). The results of research on the nutritive value of this product are, however, disappointing, and the tendency is to use coconut meal in ruminant feeding rather than in the diets of non-ruminants, although it is for the latter that the need is more urgent. Results for the nutritive value of coconut meal have been reviewed by Mitchell, Hamilton \& Beadles (1945) and Curtin (1958).

It would seem likely that a considerable amount of damage is done to the protein of coconut meal during processing and that a product of better quality could be obtained were less severe methods used. Jones, Finks \& Johns (1923) found no difference in biological value between solvent-extracted and screw-pressed meals, but later experiments by Mitchell et al. (1945) demonstrated that coconut meal produced by an extraction process in which the temperature never exceeded $75^{\circ}$ had a higher biological value than a product prepared by the 'usual drastic methods'.

Various workers (Lea \& Hannan, 1950; Henry \& Kon, I950; Bensabat, Frampton, Allen \& Hill, 1958) have shown that one of the changes accompanying severe processing conditions is a combination of the $\epsilon$-amino group of lysine with the keto group of a carbohydrate. It has been suggested that this reaction biologically inactivates the amino acid and it has been shown that for certain proteins the measurement of 'available lysine' provides an indication of nutritive value (Carpenter, Ellinger, Monroe \& Rolfe, I957; Lea, Parr \& Carpenter, I960; Clegg, I960; Boyne, Carpenter \& Woodham, 196r). In view of the fact that figures quoted by Curtin (1958) and Peters (1960) indicate that lysine is the most limiting amino acid in coconut protein, it is probable that inactivation of lysine during processing is one factor contributing to the low nutritive value of commercially produced coconut meal.

It has been shown for other feed ingredients that the solubility of protein in various solvents is decreased by heating and that this effect may be indirectly related to

- Present address: Universidad Central de Venezuela, Facultad de Ciencias Veterinarias, Maracay, Venezuela. 
nutritive value. This aspect as well as others concerned with the evaluation of protein quality by chemical methods, has been extensively reviewed by Duckworth (1955) and Grau \& Carroll (1958).

To investigate these effects, samples of coconut meal were prepared in the laboratory and subjected to various degrees of heat treatment. The resulting products were then evaluated by both chemical and physicochemical means (the determination of available lysine and solubility in various solvents). So that the effects of heat treatment on nutritive value could be examined, determinations of net protein utilization (NPU) were made with the rat. This biological evidence also allowed comparisons to be made between assessment of NPU and chemical methods, so as to find out whether one of them could be used to predict nutritive value. Such predictions could be of value in evaluating different methods of processing and also in estimating the nutritive value of a meal when time or facility for biological determinations is not available.

\section{EXPERIMENTAL}

\section{Preparation of samples}

Locally produced sun-dried copra was obtained and after grinding was extracted with cold light petroleum (b.p. $62-82^{\circ}$ ) in a vertical column until the oil content was reduced to about $8 \%$. The residue was divided into six samples. One sample was subjected for 30 min to $90,105,120,135$ or $150^{\circ}$. Heating was carried out in a forceddraught oven, and the samples were gently agitated from time to time to ensure even exposure to the heat. The sixth sample was dried at $40^{\circ}$ under reduced pressure. In a preliminary experiment it had been shown that these treatments gave a range of heat damage from negligible to severe; they were also similar to the temperatures and times encountered in the screw-press method of oil extraction. The product contained before heating: moisture $12 \cdot 6$, crude protein $23 \cdot 6$, crude fibre $10 \cdot 0$, ether extract $8 \cdot 2$, ash $6.0 \%$ (air-dry basis).

A commercially manufactured (screw-press) sample was also included in the tests for purposes of comparison.

\section{Biological measurements}

NPU was measured by the method of Miller \& Bender (1955) with 30-day-old white rats of the Wistar strain, bred in the Physiology Department, University of the West Indies.

The ratio, body nitrogen: water content of rats of this colony $\mathrm{I}-50$ days old had been previously determined; variability was found to be within the limits of biological variation inherent in the measurement of .NPU. Body $\mathrm{N}$ was therefore calculated from the water contents of the animals' bodies by means of the mean $\mathrm{N}$ : water ratio.

$\mathrm{N}$ digestibility was determined over a 7 -day period with similar animals. The formula used to calculate true $\mathrm{N}$ digestibility was:

$$
\text { true } \mathrm{N} \text { digestibility }=\frac{F N-\left(F a N-F a N_{k}\right)}{F N},
$$

where $F N=$ dietary $\mathrm{N}$ intake of the animals on the experimental diet, $F a N=$ faecal 
$\mathrm{N}$ of the test animals and $\mathrm{FaN}_{k}=$ faecal $\mathrm{N}$ of the animals on the non-protein diet. Crude protein was determined by the Kjeldahl procedure, a factor of 6.25 being used.

\section{Chemical and physicochemical measurements}

Available lysine was estimated by the method of Conkerton \& Frampton (1959) which had previously proved satisfactory for determining available lysine in vegetable protein concentrates. It depends on the reaction of the free $\epsilon$-amino group of lysine with 2,4-dinitrofluorobenzene, yielding after hydrolysis $\epsilon-2,4$-dinitrophenyllysine, which is determined spectrophotometrically. Recovery checks were made on repre-

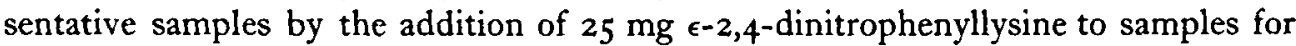
parallel determinations immediately before hydrolysis.

Fractionation in various solvents was done by the method of Lund and Sandstrom (1943) into albumins, globulins, prolamines and glutelins, depending upon their successive solubility in water, $5 \%(\mathrm{w} / \mathrm{v}) \mathrm{HCl}, 70 \%(\mathrm{v} / \mathrm{v})$ ethanol and $0.2 \%(\mathrm{w} / \mathrm{v}) \mathrm{KOH}$, respectively; any protein insoluble in these solvents was called 'residual protein'.

Solubility was determined in $0.02 \mathrm{~N}-\mathrm{NaOH}$ by the method of Lyman, Chang \& Couch (1953) and also determined in $6 \mathrm{~N}-\mathrm{HCl}$ and in $0.5 \mathrm{M}-\mathrm{NaCl}$ by similar methods. It was found that centrifugation was insufficient to clarify the solutions unless high speeds were employed, and filtration was therefore used.

Besides the above-mentioned samples assayed by biological and other methods, other samples of coconut meal were collected from various sources, and their available lysine contents were determined to obtain an approximate measure of the variability to be expected among commercially available samples.

\section{RESULTS}

The values obtained for NPU and the coefficient of true $\mathrm{N}$ digestibility are shown in Table $\mathrm{r}$, together with the calculated biological value. There was a distinct decline in nutritive value as the degree of heat treatment increased.

Statistical analysis of the results revealed the following:

(I) There was no significant difference between the mean NPU values of the coconut meal vacuum-dried at $40^{\circ}$ and of that treated at $90^{\circ}$.

(2) No significant differences existed among the meals treated at I05, 120 and $135^{\circ}$ and the commercial meal.

(3) The NPU of the meals treated at 40 and $90^{\circ}$ each differed significantly from that of the meal treated at $150^{\circ}(P<0.01)$ and from that of a commercial meal $(P=0.05)$.

(4) The differences in NPU between each of the meals treated at $105,120,135^{\circ}$ and that treated at $150^{\circ}$ were significant $(P=0.05)$.

The results of the various chemical and physicochemical methods used together with the correlation coefficients between these criteria and NPU, with the levels of significance at which they were different from zero, are set out in Table 2.

It will be seen that positive correlations always existed except for residual protein, for which the value was negative.

The closest correlations were between the values for available lysine and NPU 
$(r=0.9 \mathrm{I} ; P<0.0 \mathrm{I})$ and between those for $\mathrm{HCl}$-soluble protein and NPU $(r=0.90$;

$P<0.01$ ).

Values for available lysine for the miscellaneous samples collected are given in Table 3, together with type of production conditions when known. Values for NPU computed from the available-lysine values have also been given.

Table I. Net protein utilization, digestibility and biological value of coconut meal subjected to various degrees of heat treatment

\begin{tabular}{|c|c|c|c|c|}
\hline $\begin{array}{l}\text { Temperature of } \\
\text { treatment } \\
\left({ }^{\circ} \mathrm{C}\right)\end{array}$ & $\begin{array}{l}\text { Protein } \\
\text { content } \\
(\%)\end{array}$ & NPU* & $\begin{array}{c}\text { Coefficient of } \\
\text { true } N \\
\text { digestibility }\end{array}$ & $\begin{array}{l}\text { Biological } \\
\text { value (by } \\
\text { calculation } \dagger \text { ) }\end{array}$ \\
\hline 40 & 25.3 & $45.9(3)$ & $77 \cdot 7(2)$ & $59 \cdot 1$ \\
\hline 90 & 25.8 & $41 \cdot 0(3)$ & $78 \cdot 3(2)$ & $52 \cdot 4$ \\
\hline 105 & $26 \cdot 3$ & $3^{6} \cdot 1(3)$ & $74 \cdot 6(3)$ & 48.4 \\
\hline 120 & $25 \cdot 6$ & $35.8(2)$ & $73.3(2)$ & 48.8 \\
\hline r 35 & $26 \cdot 4$ & $33.9(2)$ & $68 \cdot 2(2)$ & 49.7 \\
\hline 150 & $26 \cdot 3$ & $17 \cdot 1(4)$ & $56 \cdot I \quad(3)$ & 30.5 \\
\hline $\begin{array}{l}\text { Commercial } \\
\text { sample }\end{array}$ & 25.4 & $30.0(3)$ & $75 \circ(2)$ & 40.0 \\
\hline Standard deviation & - & \pm 5.39 & \pm 3.52 & - \\
\hline
\end{tabular}

Table 2. Amounts (\%) of total protein soluble in various solvents, available-lysine content, and correlation coefficients between these values and net protein utilization, for coconut meal subjected to various heat treatments

\begin{tabular}{|c|c|c|c|c|c|c|c|c|c|}
\hline \multirow[b]{2}{*}{$\begin{array}{l}\text { Temperature } \\
\text { of treatment } \\
\left({ }^{\circ} \mathrm{C}\right)\end{array}$} & \multicolumn{3}{|c|}{$\begin{array}{l}\text { Total protein } \\
\text { solubility in: }\end{array}$} & \multicolumn{5}{|c|}{ Lund-Sandstrom fractionation } & \multirow[b]{2}{*}{$\begin{array}{c}\text { Available } \\
\text { lysine } \\
(g / \log N)\end{array}$} \\
\hline & $6 \mathrm{~N}-\mathrm{HCl}$ & $\begin{array}{l}0.5 \mathrm{M}- \\
\mathrm{NaCl}\end{array}$ & $\begin{array}{l}0.02 \mathrm{~N}- \\
\mathrm{NaOH}\end{array}$ & Albumin & Globulin & $\begin{array}{l}\text { Prol- } \\
\text { amine }\end{array}$ & Glutelin & Residual & \\
\hline 40 & 55.4 & $5 \times 4$ & $27 \cdot 1$ & $15 \cdot 3$ & $34 \cdot 5$ & $2 \cdot 6$ & I $7 \cdot 1$ & 30.5 & 3.29 \\
\hline 90 & $57 \cdot 5$ & $50 \cdot 2$ & $26 \cdot 6$ & 16.7 & $37 \cdot 7$ & $r \cdot 8$ & $17 \cdot 4$ & $26 \cdot 4$ & 3.09 \\
\hline 105 & $48 \cdot 4$ & $45 \cdot 8$ & 25.4 & 14.4 & $33 \cdot 8$ & $1 \cdot 4$ & $15^{\circ} 1$ & $35 \cdot 3$ & $2 \cdot 8 I$ \\
\hline 120 & $42 \cdot 8$ & $15 \cdot 2$ & 19.9 & $9 \cdot 4$ & $8 \cdot 9$ & $1 \cdot 4$ & 16.0 & $64: 3$ & $2 \cdot 34$ \\
\hline 135 & $20 \cdot I$ & $6 \cdot 8$ & $6 \cdot 2$ & 5.4 & $I \cdot 2$ & 0.7 & $4 \cdot 1$ & $88 \cdot 6$ & 1.63 \\
\hline I 50 & $7 \cdot 0$ & 3.9 & $2 \cdot 1$ & $3 \cdot 8$ & 0.6 & 0.6 & $1 \cdot 4$ & $93 \cdot 6$ & $I \cdot 12$ \\
\hline $\begin{array}{l}\text { Commercial } \\
\text { sample }\end{array}$ & $24 \cdot 2$ & 6.8 & 5.5 & $5 \cdot 6$ & $x \cdot 8$ & 0.3 & $4 \cdot I$ & $88 \cdot 2$ & 1.98 \\
\hline $\begin{array}{l}\text { Correlation } \\
\text { coefficient } \\
\text { between } \\
\text { value and NPU }\end{array}$ & 0.90 & 0.78 & 0.84 & 0.82 & 0.74 & 0.74 & 0.83 & -0.73 & 0.91 \\
\hline $\begin{array}{l}\text { Level of sig- } \\
\text { nificance, } P<\end{array}$ & 0.01 & 0.05 & 0.02 & 0.05 & 0.10 & 0.10 & 0.05 & 0.10 & 0.01 \\
\hline
\end{tabular}

\section{DISCUSSION}

The values obtained for available lysine were in reasonable agreement with the value of $4 . \mathrm{I} / \mathrm{I} 6 \mathrm{~g} \mathrm{~N}$ for total lysine obtained by Peters ( 1960 ), if it is assumed that the lysine is about $80 \%$ available. This level of availability is similar to that obtained by Clegg ( 1960$)$ for the percentage availability of the lysine in dried-milk powder and to values 
determined biologically for various materials of both vegetable and animal origin and quoted in a recent review by Guttridge (1962).

The values for total lysine quoted by Curtin (1958), which ranged from $2 \cdot 2$ to $2.8 \mathrm{~g} / \mathrm{r} 6 \mathrm{~g} \mathrm{~N}$, are considerably lower than would be expected from either the values found by us or those of Peters (1960), but it is clear that there is wide variation among samples of the material.

Table 3. Contents of available lysine and the predicted net protein utilization of various commercially produced samples of coconut meal

$\begin{array}{lcc}\begin{array}{c}\text { Origin of sample and } \\ \text { method of preparation }\end{array} & \begin{array}{c}\text { Available lysine } \\ (\mathrm{g} / \mathrm{1} 6 \mathrm{~g} \mathrm{~N})\end{array} & \begin{array}{c}\text { NPU } \\ \text { (predicted) }\end{array} \\ \begin{array}{c}\text { 1. Trinidad; } \\ \text { screw-press }\end{array} & 1.98 & 30.7 \\ \begin{array}{l}\text { 2. Trinidad; } \\ \text { screw-press }\end{array} & 0.96 & 20.0 \\ \text { 3. St Lucia } & & \\ \text { 4. France (A); } & 2.07 & 35.6 \\ \text { solvent } & 2.56 & 36.8 \\ \begin{array}{l}\text { 5. France (B); } \\ \text { solvent }\end{array} & 2.49 & 36.0 \\ \text { 6. UNICEF; } & 3.69 & 48.5 \\ \text { solvent (prepared } \\ \text { for human con- } \\ \text { sumption) }\end{array}$

* Used in determinations reported in Tables $\mathrm{I}$ and 2.

$t$ Method unknown.

The mean recovery of 2,4-dinitrophenyllysine was $80 \%$, which was similar to the $74 \%$ obtained by Carpenter \& March (196x) using the method of Carpenter (I960) to determine the availability of lysine in groundnut biscuits.

The results of the NPU determinations on the vacuum-dried meal were in good agreement with values of 48 and 50 obtained by one of us (H.C.F.) for fresh solvent-extracted coconut meal prepared from coconuts grown in Jamaica. The biological value of this meal was similar to that of 58 reported by Mitchell \& Villegas (1923), but lower than that (7I) reported later by Mitchell et al. (1945) for a solvent-extracted meal during whose processing the temperature did not rise above $75^{\circ}$. It seems likely that the inferiority of our vacuum-dried meal to this solvent-extracted meal was due less to processing conditions than to differences in the copra from which the meals were made, as it has been shown in the work described here that little deterioration in protein quality is to be expected between temperatures of 40 and $90^{\circ}$. The low NPU obtained for the untreated copra meal used in these experiments was partly due to the low $\mathrm{N}$ digestibility, $78 \%$, which is somewhat lower than that of $86 \%$ obtained by Mitchell et al. (1945) and $89 \%$ obtained by Smuts \& Malan (1938). In preparing the samples of coconut meal, no attempt was made to reduce the fibre content, and the low digestibility may well be related to the high fibre content of the meal (10.0\%).

It is clear from the results quoted in Table I that there was a significant decline in 
nutritive value, expressed both as NPU and as $\mathrm{N}$ digestibility, with increasing severity of processing conditions. This decline was slight in samples heated at from 40 to $90^{\circ}$, but in those treated at from $105^{\circ}$ upwards it was considerable. It may be seen from Table 2 that the values for available lysine declined in a similar manner, and in fact the close correlations between the sets of measurements suggest that the corresponding regression equations could be usefully employed for the prediction of nutritive values of various samples of coconut meal. Although $\mathrm{HCl}$-soluble protein also showed a similar decline with increased temperature, replication was more difficult to obtain, and it was considered that the determination of available lysine was the more reliable method.

The equation relating available lysine and NPU has been calculated and is:

$$
y=10 \cdot 1+10 \cdot 43 x
$$

where $y=\mathrm{NPU}$ and $x=$ available lysine in $\mathrm{g} / \mathrm{I} 6 \mathrm{~g} \mathrm{~N}$.

It is interesting to note that the critical temperature range $\left(90-150^{\circ}\right)$ in this series of experiments was the same as that commonly encountered during the cooking process carried out before screw-press extraction. Further heat damage may be suffered by the protein of the meal during the extraction process. With cottonseed and soya-bean meals, moderate heat treatment is advantageous because it inactivates toxic constituents; coconut meal, however, can be affected only adversely by heat treatment. In Table 3, values determined for the content of available lysine of various commercial samples are listed; the regression equation relating NPU and available lysine content has been used to predict the nutritive value of these samples. It may be seen that large differences existed from sample to sample. As would be expected, the UNICEF sample, which was prepared with considerable care for human consumption, had a higher value than any of the others, and the solvent-extracted meals were better than those extracted by screw-press methods. Unfortunately, processing temperatures are not known for all the screw-press meals, but it is known that the processing temperature of meal 7 was considerably lower than of meals $I$ and 2 . It would have been desirable to carry out NPU determinations on these commercial samples in order to provide additional evidence for the validity of the prediction equation; unfortunately, however, this was impossible.

Although there was a high correlation between the contents of available lysine and the nutritive values of the coconut meal, it is not inferred that this is the only amino acid that suffers heat damage during processing. Donoso, Lewis, Miller \& Payne (1962) showed that in pork heated with water there was a considerable decrease in the extent to which the sulphur-containing amino acids were utilized, and it is probable that a better prediction of nutritive value could be made by including a measure of the destruction of these acids.

It would seem therefore that, in general, the nutritive value of coconut meal could be improved by the use of less drastic processing methods. In view of the important work recently reported by Subrahmanyan and his associates (see, for example, Subrahmanyan, Doraiswamy, Bhagavan, Tasker, Sankaran, Rajagopalan \& Swaminathan, 1959; Tasker, Rao, Swaminathan \& Subrahmanyan, 1959) on the beneficial 
effects on children of dietary supplements containing $25 \%$ coconut meal, it is clear that this material could have an important part to play in tropical nutrition, both of animals and man. Attention should therefore be paid to producing a meal with as high a nutritive value as possible by keeping the processing temperature to a minimum.

\section{SUM MAR Y}

I. Five samples of coconut meal were prepared in the laboratory by solvent extraction and were subjected to a temperature of $90,105,130$ or $150^{\circ}$. A sample similarly prepared but dried under reduced pressure and a sample of commercial origin were also included among the materials under examination. Net protein utilization (NPU), available-lysine content, protein solubility in $6 \mathrm{~N}-\mathrm{HCl}, 0.02 \mathrm{~N}-\mathrm{NaCl}$, and LundSandstrom fractionation were determined.

2. NPU results showed that nutritive value deteriorated as processing temperature increased.

3. Values for available-lysine content and $\mathrm{HCl}$-soluble protein also decreased with the severity of heat treatment. These values were highly correlated with NPU. The other values determined also decreased with severity of heat treatment, except that for the residual protein from the Lund-Sandstrom fractionation, which increased. The correlation coefficient between several of these values and NPU was significant, but not as highly so as those between NPU and available lysine and $\mathrm{HCl}$-soluble protein.

4. The regression equation between values for NPU and available lysine was calculated; it is considered that it may be useful in predicting the nutritive value of samples of coconut meal. The equation is $y=10 \cdot 1+10 \cdot 43^{x}$ (SD of $b= \pm 4 \cdot 1$ ), where $y=\mathrm{NPU}$ and $x=$ available lysine in $\mathrm{g} / \mathrm{1} 6 \mathrm{~g} \mathrm{~N}$.

5. Determinations of available lysine were made on various samples of coconut meal, and calculations of NPU were made by means of the regression.

We are grateful to the various firms and individuals who assisted us by supplying samples of coconut meal from different sources: we would also like to express our thanks to Miss Barbara Hull for technical assistance.

\section{REFERENCES}

Bensabat, L., Frampton, V. L., Allen, L. E. \& Hill, R. A. (1958). 7. agric. Fd Chem. 6, 778.

Boyne, A. W., Carpenter, K. J. \& Woodham, A. A. (1961). Y. Sci. Fd Agric. 12, 832.

Carpenter, K. J. (1960). Biochem. Y. 77,604.

Carpenter, K. J., Ellinger, G. M., Monroe, M. I. \& Rolfe, E. J. (1957). Brit. F. Nutr. Ix, 162.

Carpenter, K. J. \& March, B. E. (1961). Brit. J. Nutr. 15, 403.

Clegg, K. M. (1960). Brit. F. Nutr. 14, 325.

Conkerton, E. J. \& Frampton, V. L. (1959). Arch. Biochem. Biophys. 81, i 30.

Curtin, L. V. (1958). In Processed Plant Protein Foodstuffs, p. 645. [A. M. Altschul, editor.] New York: Academic Press Inc.

Donoso, G., Lewis, O. A. M., Miller, D. S. \& Payne, P. R. (rg62). Y. Sci. Fd Agric. 13, 192.

Duckworth, J. (1955). In Modern Methods of Plant Analysis. Vol. 4, p. 1o6. [K. Paech and M. V. Tracey, editors.] Berlin: Springer Verlag.

Grau, C. R. \& Carroll, R. W. (1958). In Processed Plant Protein Foodstuffs, p. 153. [A. M. Altschul, editor.] New York: Academic Press Inc.

Guttridge, D. G. A. (1962). In Nutritton of Pigs and Poultry', p. 57. [J. T. Morgan and D. Lewis, editors.] London: Butterworth and Co. (Publishers) Ltd. 
Henry, K. M. \& Kon, S. K. (r950). Biochim. biophys. Acta, 5, 455.

Jones, D. B., Finks, A. J. \& Johns, C. O. (1923). Y. agric. Res. 24, 971.

Lea, C. H. \& Hannan, R. S. (1950). Biochim. biophys. Acta, 4, 518.

Lea, C. H., Parr, L. J. \& Carpenter, K. J. (1960). Brit. Y. Nutr. I4, 9 r.

Lund, A. P. \& Sandstrom, W. M. (1943). F. agric. Res. 66, 349.

Lyman, C. M., Chang, W. Y. \& Couch, J. R. (1953). F. Nutr. 49, 679.

Miller, D. S. \& Bender, A. E. (1955). Brit. Y. Nutr. 9, 382.

Mitchell, H. H., Hamilton, T. S. \& Beadles, J. R. (1945). J. Nutr. 29, 13.

Mitchell, H. H. \& Villegas, V. (1923). F. Dairy Sci. 6, 222.

Peters, F.E. (1960). Preparation and amino acid composition of selected seed protein fractions. Ph.D. Thesis, University of Purdue.

Smuts, D. B. \& Malan, A. I. (1938). Onderstepoort f. vet. Sci. ro, 207.

Subrahmanyan, V., Doraiswamy, T. R., Bhagavan, R. K., Tasker, P. K., Sankaran, A. N., Rajagopalan, R. \& Swaminathan, M. (1959). Ann. Biochem. $19,147$.

Tasker, P. K., Rao, M. N., Swaminathan, M. \& Subrahmanyan, V. (1959). Ann. Biochem. 19, 153. 